\title{
Statistical analysis of the width of permanent geological deformation zone under strong earthquake with faulting rupture
}

\author{
a Jianyi ZHANG, Jingshan BO\& Jing TIAN, ${ }^{\mathrm{b}}$ Zhenyu WANG \& Jingshan BO \\ alnstitute of Disaster Prevention, Sanhe Hebei, China \\ bInsitutute of Engineering Mechanics, China Earthquake Administration, Harbin, China
}

\begin{abstract}
KEYWORD: Surface rupture; permanent geological deformation zone; setback distance; statistical analysis

ABSTRACT: Slipping of active faults, under some conditions, generates surface rupture which can damage the structures in the rupturing zones. One of the key core is a basic characteristic of surface rupture are systematically summarized and analyzed, especially the statistical analysis of surface rupture width, this paper on width of geological permanent deformation detailed statistics, analysis, it is concluded that: (1) fracture zone width statistical method gives the surface rupture permanent geological deformation of the upper limit of the width value and can be used to quantify the average value; (2) profile trench statistical method to determine the surface rupture width more economical and reliable, such as to establish of the scarps vertical height $(\mathrm{H})$ and maximum deformation with the formula of width $\left(\mathrm{W}_{\mathrm{D}}\right)$, or strong deformation zone width average value and several times the standard deviation of the formula.
\end{abstract}

\section{INTRODUCTION}

The current seismic fortification measures are difficult to prevent the surface rupture dislocation of the direct damage to the lifeline and buildings. Especially, the earthquakes above magnitude 7 are often caused by dislocation surface of a few meters and heavy disaster has a narrow belt along the seismogenic fault distribution (Xu Xiwei et al.2011, Zhang Jianyi et al.2010), built on the dislocation with building the damage is not easy to use engineering measures to be avoided, and even the surface rupture wherever he went to is indestructible.

Therefore, for possible surface rupture of the fault, must avoid. This relates to the surface rupture and the possibility of setback distance, namely earthquake surface rupture of scientific prediction and setback distance is to determine the issue in the field of rock soil engineering seismic and seismic geology research is focus of released by the problem of urban earthquake disaster mitigation planning and active faults. And the key is as the object of study of the surface rupture zone, seismic surface rupture show a large variety of deformation and damage phenomenon (i.e., the characteristics of the surface rupture) is any physical test difficult to simulate and by other methods, such as numerical analysis, which cannot be made, is the study of the surface rupture of the most basic, most reliable and most detailed valuable data, especially the recent near buildings earthquake surface rupture characteristics is a rare material.

For the surface rupture characteristics of strong earthquakes, the width of the surface rupture zone and the permanent geological deformation zone of strong earthquake are analyzed in detail. Among them, the earthquake surface rupture zone width refers to the width of surface area earthquake caused by vertical surface rupture of faults and the trend of significant deformation, because of strong earthquakes and earthquake surface rupture is compared, the lower probability event, such as 2010 to more than one hundred years, Chinese, a total of more than 6 magnitude earthquake approximate 362 times, only 34 earthquakes produce the scale range of surface rupture(Sun Pingshan.2009), for a lot of surface rupture was not detailed investigation; and strong earthquake permanent geologic deformation zone width method is to use the ancient seismic deformation pattern, deformation type, deformation intensity, effective method to determine the actual width of the fault rupture, and can compensate for the lack of strong earthquake surface rupture with data.

About the statistical width of earthquake surface permanent geological deformation belt, this paper argues that there can be two ways: (1) the fracture zone width statistic method, fracture zone mainly 
refers to the possible late Quaternary (mostly before middle Pleistocene before) rock mass in its multi stages of rupture events to a fracture zone width, which is help to reveal the greatest impact on engineering site trace fault width stage; (2) trench profile statistics, use the profile exploratory trench statistics normally only given strong permanent geological deformation belt, all can't give the surface rupture zone with width, while geological permanent deformation happened to bring scarp geological topographic profile can make up for the width of the trench is insufficient..

\section{METHOD OF FRACTURE ZONE WIDTH}

Huangfugang (1993) number ten times into the area of the northwest of Yunnan Province on a number of faults of different degree of study, in this paper based on the statistics of faults are all after a detailed investigation to determine for secondary development degree of faults, namely the region 33 small faults in 48 sets of faults of broken belt width of the statistics.

Analysis these data, with two sets of lithology the old broken, with the wider width of the rock breaking; statistical older that may actually is through the surface rupture of the late Quaternary hard soil layer, or the western region to soil, gravel (breccia) based "two element" soil layer permanent geological surface rupture the deformation of the width of the upper limit value, which is also equivalent to Glenn Borchardt's (2010) "free soil" activity ages T and shear bands distance width was positively correlated to provide data validation; Finally, whether it is for both horizontal fault length in these data, big such as A class, or small fault length, such as class B, the numerical change is greater also, reflecting the local deformation characteristics of the fracture zone width, the level of the same length, the fracture zone width change in value is differ, concrete analysis is: $21 \mathrm{~A}$ class data of average of $143 \mathrm{~m}$, the standard deviation for the $99 \mathrm{~m} ; 27$ B class data averages $33 \mathrm{~m}$, the standard deviation of $20 \mathrm{~m}$.

In a word, the surface rupture zone width should be determined rationally, can be considered broke (break) take place of the earth's surface rupture segmentation fault (level) in more than $10 \mathrm{~km}$ in length, the maximum surface fracture zone width is $143 \mathrm{~m}$, the standard deviation of $99 \mathrm{~m}$; In the following $10 \mathrm{~km}$, the maximum surface fracture zone width is $33 \mathrm{~m}$, the standard deviation of $20 \mathrm{~m}$.

\section{STATISTICAL METHOD OF PROFILE OF EXPLORATORY TRENCH}

\section{Width of statistical analysis of the complete surface permanent geological deformation zone}

Except the exploratory trench excavation section, if the point of the surface rupture or micro geomorphology is not man-made or natural change, etc., can be combined with that point scarp and its geological profile (terrain), gives a real (or maximum) earthquake surface permanent geological deformation band width, such as Xinjiang Urumqi active faults exploration project in Wangjiagou, nine Bay fault exploration groove scarp deformation profile analysis, survey is given of the Wangjiagou strong deformation band width data by Chuan-yong Wu (2001),see in Table 1.

From these data in Table 1, can get Wangjiagou third terrace surface scarps height (vertical dislocation) for $0.4-1.6 \mathrm{~m}$, maximum deformation band width is about $50 \mathrm{~m}$; Middle Pleistocene terrace scarp height most 1.5-5.0m, maximum deformation band width of about $85 \mathrm{~m}$.

In this paper, the 33 Chinese pleistocene gravel terrace from these data under normal distribution was performed to calculate the mean and standard deviation of the results as follows: the average 43 $\mathrm{m}$, the standard deviation of $13 \mathrm{~m}$; And in combination with 39 scarp vertical height $(\mathrm{h})$ and the maximum deformation band width ( $\mathrm{Wd})$, fitting the relationship for $\mathrm{Wd}=\mathrm{U}(29.5+4.5 \mathrm{~h})$, which is suitable for the safety factor of the envelope, $\mathrm{U} 2$ of advice.

Table 1. Strong geological deformation of Wang Gugou fault group with the measured values.

Fau Faulted landform Vertical Strong de-




\begin{tabular}{|c|c|c|c|}
\hline lt & unit & $\begin{array}{l}\text { disloca- } \\
\operatorname{tion}(\mathrm{m})\end{array}$ & $\begin{array}{c}\text { formation } \\
\text { band } \\
\text { width }(\mathrm{m})\end{array}$ \\
\hline \multirow{3}{*}{ F1 } & Wanoiiaonll III ter- & $\cap 4$ & $2 n$ \\
\hline & Wanoiiaonu III ter- & 16 & 78 \\
\hline & Wanoiiaonu III ter- & 21 & 40 \\
\hline \multirow{17}{*}{$\mathrm{F} 2$} & Middle Pleistoneene & 33 & 44 \\
\hline & Pleistocene & 37 & $87 *$ \\
\hline & Middle Pleistocene & 37 & 64 \\
\hline & Middle Pleistocene & 1.6 & 40 \\
\hline & Middle Pleistocene & 32 & 37 \\
\hline & Pleistocene & 37 & 2.7. \\
\hline & Middle Pleistocene & 37 & $4 n$ \\
\hline & Middle Pleistocene & 7. 7 . & 7.8 \\
\hline & Middle Pleistocene & 2.5 & 28 \\
\hline & Pleistocene & 41 & 31 \\
\hline & Middle Pleistocene & 41 & 50 \\
\hline & Middle Pleistocene & 4.2 & 48 \\
\hline & Pleistocene & 48 & 67. \\
\hline & Wanoiiaonil III ter- & 10 & 30 \\
\hline & Pleistocene & 2. 4 & 54 \\
\hline & Pleistocene & 37 & 38 \\
\hline & Pleistocene & 34 & 41 \\
\hline \multirow{15}{*}{ F3 } & Pleistorene & 10 & 77 \\
\hline & Middle Pleistorene & 10 & 36 \\
\hline & Pleistncene & 76 & 43 \\
\hline & Middle Pleistncene & 20 & 50 \\
\hline & Pleisterene & 17 & 35 \\
\hline & Pleistncene & 71 & 44 \\
\hline & Pleistncene & 14 & 65 \\
\hline & Pleistocene & 15 & 47 \\
\hline & Pleistencene & 7.4 & 38 \\
\hline & Wanoiiaonll III ter- & 14 & $4 n$ \\
\hline & Wanoiiaonil III ter- & 09 & 28 \\
\hline & Wanoiiaonil III ter- & $1 \cap$ & 36 \\
\hline & Middle Pleistorene & 57 & 50 \\
\hline & Pleistncene & 57 & 48 \\
\hline & Middle Pleistocene & 37 & 32 \\
\hline \multirow{4}{*}{$\mathrm{F} 4$} & Pleistncene & 18 & 25 \\
\hline & Pleistocene & 36 & 37. \\
\hline & Pleistocene & 37 & 50 \\
\hline & Pleistocene & 36 & 50 \\
\hline
\end{tabular}

Width of statistical analysis of the incomplete surface permanent geological deformation zone If the length of the longitudinal section of the channel is not complete, or can only give a part of the width of the permanent geological deformation which is reflected by the section of the channel, it is needed to find another method. For not all given permanent geological deformation with the width of the trench, the American James McCalpin (1987) was a pioneering work: on Utah's Wasatch fault belt occurred on the surface rupture and adjacent to the break 40 trench records were collected and analyzed, and gives the area is permanent fault surface geological deformation width statistical analysis model, which is based on the average value and twice or three times the standard deviation gives the final statistical analysis of avoidance width.

Thus, this paper systematically for the first time to finishing the previous to the surface rupture with a detailed study of the Fuyun earthquake (Fuyun earthquake fault zone), Haiyuan earthquake (earthquake in Haiyuan fault zone seismic), the Altyn Tagh fault zone, active CHANGMA FAULT ZONE, with the Kunlun Mountain earthquake, Yinchuan activity detecting layer in the trench records (trench profiles) and other related articles in the trench characteristics of the surface rupture(Zhang Jianyi 2015), thoroughly analyzed in detail, see table 2.

Through the above analysis, this paper can use proposed James McCalpin average value and twice or three times the standard deviation of numerical and as a permanent geological deformation band width of the so-called "real" or the "greatest" value, of course, for the specific trench also consider the characteristics of the internal structure and accumulative total vertical dislocation, etc.

From table 2 shows, this method mainly is can rupture internal structure parameters and rupture: the width of the quantitative correlation analysis, which can reduce the active fault location of the cover 
layer thickness of the lithology, thickness and fault itself geometric structure factors, determined by the width of the more economical and reliable.

Through the establishment of the trench permanent geological deformation width a large number of valuable data table 2, with normal distribution, given the previous earthquake caused the surface rupture trace maximum width Wo averages $5.5 \mathrm{~m}$, standard deviation is $4.0 \mathrm{~m}$, and shows that the surface rupture trace maximum width Wo 10-15m; probe trench on the geology strong deformation belt width $\mathrm{W}_{\mathrm{Y}}$ average value for $10.2 \mathrm{~m}$, the standard deviation of $5.4 \mathrm{~m}$ and permanent known geological deformation band width $\mathrm{W}_{\mathrm{Y}}$ for $20-25 \mathrm{~m}$.

\section{CONCLUSIONS}

Table 2. Rupture characteristics of the exploratory trench profile of the list

\begin{tabular}{|c|c|c|c|c|c|c|}
\hline $\begin{array}{l}\mathrm{N} \\
\mathrm{o}\end{array}$ & $\begin{array}{c}\text { Faul } \\
t \\
\text { type }\end{array}$ & $\begin{array}{l}\text { Coverage } \\
\text { and soil de- } \\
\text { scription }\end{array}$ & $\begin{array}{c}\mathrm{W}_{\mathrm{o}} / \\
\mathrm{m}\end{array}$ & $\begin{array}{c}\text { Num } \\
\text { ber }\end{array}$ & $\begin{array}{c}\mathrm{W}_{\mathrm{Y}} / \\
\mathrm{m}\end{array}$ & $\theta\left(^{\circ}\right)$ \\
\hline 1 & $\begin{array}{l}\text { Nor } \\
\text { mal }\end{array}$ & $\begin{array}{l}\text { Silty sand, } \\
\text { gravel and } \\
\text { sand. }\end{array}$ & 8.1 & 5 & 11.9 & $\begin{array}{l}65^{\circ}- \\
82^{\circ}\end{array}$ \\
\hline 2 & $\begin{array}{l}\text { Nor } \\
\text { mal }\end{array}$ & $\begin{array}{l}\text { Loose grav- } \\
\text { el }\end{array}$ & 3.2 & 4 & 8.2 & $88^{\circ}$ \\
\hline 3 & $\begin{array}{l}\text { Nor } \\
\text { mal }\end{array}$ & $\begin{array}{l}\text { Silty sand } \\
\text { and gravel }\end{array}$ & 3.7 & 5 & 13.3 & $\begin{array}{l}62^{\circ}- \\
90^{\circ}\end{array}$ \\
\hline 4 & $\begin{array}{l}\text { Nor } \\
\text { mal }\end{array}$ & $\begin{array}{l}\text { Silty sand } \\
\text { clay, } \\
\text { sand, gravel }\end{array}$ & $\begin{array}{c}4.8 \\
5\end{array}$ & 3 & $9.4^{*}$ & $\begin{array}{l}68^{\circ}- \\
80^{\circ}\end{array}$ \\
\hline 5 & $\begin{array}{l}\text { Nor } \\
\text { mal }\end{array}$ & $\begin{array}{l}\text { Sand, gravel } \\
\text { and silty } \\
\text { sand }\end{array}$ & 2.9 & 3 & 6.0 & $44^{\circ}$ \\
\hline 6 & $\begin{array}{l}\text { Nor } \\
\text { mal }\end{array}$ & $\begin{array}{l}\text { River ter- } \\
\text { race }\end{array}$ & 0.3 & 1 & 3.8 & $65^{\circ}$ \\
\hline 7 & $\begin{array}{l}\text { Nor } \\
\text { mal }\end{array}$ & $\begin{array}{l}\text { Gravel and } \\
\text { silt compo- } \\
\text { sition }\end{array}$ & 0.2 & 1 & 4.7 & $53^{\circ}$ \\
\hline 8 & $\begin{array}{l}\text { Nor } \\
\text { mal }\end{array}$ & $\begin{array}{l}\text { Medium fi- } \\
\text { ne sand, } \\
\text { gravel }\end{array}$ & 0.5 & 1 & 4.0 & $65^{\circ}$ \\
\hline 9 & $\begin{array}{l}\text { Nor } \\
\text { mal }\end{array}$ & $\begin{array}{l}\text { Silty sand } \\
\text { clay, sand, } \\
\text { gravel com- } \\
\text { position }\end{array}$ & 4.1 & 2 & 11.7 & $\begin{array}{l}73^{\circ} \\
78^{\circ}\end{array}$ \\
\hline 10 & $\begin{array}{l}\text { Nor } \\
\text { mal }\end{array}$ & $\begin{array}{l}\text { Loose allu- } \\
\text { vial deposits } \\
\text { of gravel } \\
\text { and loess }\end{array}$ & 4.3 & 3 & 24 & $70^{\circ}$ \\
\hline 11 & $\begin{array}{l}\text { Nor } \\
\text { mal }\end{array}$ & $\begin{array}{l}\text { Alluvial de- } \\
\text { posits, sec- } \\
\text { ondary loess }\end{array}$ & 6.5 & 4 & 13.5 & $70^{\circ}$ \\
\hline 12 & $\begin{array}{l}\text { Nor } \\
\text { mal }\end{array}$ & $\begin{array}{l}\text { Secondary } \\
\text { loess layer, } \\
\text { gravel }\end{array}$ & 12 & 6 & $\begin{array}{c}19.1 \\
*\end{array}$ & $70^{\circ}$ \\
\hline 13 & $\begin{array}{c}\text { Strik } \\
\mathrm{e}\end{array}$ & $\begin{array}{l}\text { Secondary } \\
\text { loess layer, }\end{array}$ & 6.8 & 5 & $\begin{array}{c}14.8 \\
*\end{array}$ & $75^{\circ}$ \\
\hline
\end{tabular}




\begin{tabular}{|c|c|c|c|c|c|c|}
\hline & slip & gravel & & & & \\
\hline 14 & $\begin{array}{l}\text { Strik } \\
\text { e } \\
\text { slip }\end{array}$ & $\begin{array}{l}\text { Secondary } \\
\text { loess, sub } \\
\text { sandy soil }\end{array}$ & 8.5 & 6 & $1{ }_{*}^{1.3}$ & $80^{\circ}$ \\
\hline 15 & $\begin{array}{l}\text { Nor } \\
\text { mal }\end{array}$ & $\begin{array}{l}\text { Loess, grav- } \\
\text { el, sand }\end{array}$ & 4.7 & 2 & 6.9 & $75^{\circ}$ \\
\hline 16 & $\begin{array}{l}\text { Strik } \\
\text { e } \\
\text { slip }\end{array}$ & Gravel sand & 2.1 & 5 & 3.4 & $80^{\circ}$ \\
\hline 17 & $\begin{array}{l}\text { Nor } \\
\text { mal }\end{array}$ & $\begin{array}{l}\text { Secondary } \\
\text { loess, allu- } \\
\text { vial sand } \\
\text { and gravel }\end{array}$ & 4.8 & 2 & 4.8 & $72^{\circ}$ \\
\hline 18 & $\begin{array}{l}\text { nor } \\
\text { mal- } \\
\text { strik } \\
\text { e } \\
\text { slip }\end{array}$ & $\begin{array}{l}\text { Secondary } \\
\text { loess with } \\
\text { gravel }\end{array}$ & 12 & 2 & $\underset{*}{12.3}$ & $85^{\circ}$ \\
\hline 19 & $\begin{array}{l}\text { Nor } \\
\text { mal }\end{array}$ & $\begin{array}{l}\text { Loam, sand } \\
\text { and gravel }\end{array}$ & 3.3 & 2 & 9.0 & $\begin{array}{l}70^{\circ} \\
77^{\circ}\end{array}$ \\
\hline 20 & $\begin{array}{l}\text { Strik } \\
\mathrm{e} \\
\text { slip }\end{array}$ & $\begin{array}{l}\text { Alluvial } \\
\text { sandy silty } \\
\text { clay }\end{array}$ & 4.1 & 13 & $8.5^{*}$ & $\begin{array}{l}70^{\circ}- \\
80^{\circ}\end{array}$ \\
\hline 21 & $\begin{array}{l}\text { Dip- } \\
\text { slip }\end{array}$ & $\begin{array}{l}\text { Breccia, fi- } \\
\text { ne-grained } \\
\text { deposits }\end{array}$ & 4.0 & 7 & 13.5 & $\begin{array}{l}80^{\circ}- \\
85^{\circ}\end{array}$ \\
\hline 22 & $\begin{array}{l}\text { Nor } \\
\text { mal }\end{array}$ & $\begin{array}{l}\text { Gravel and } \\
\text { gravel }\end{array}$ & 2.8 & 3 & 5.6 & $\begin{array}{l}70^{\circ}- \\
75^{\circ}\end{array}$ \\
\hline 23 & $\begin{array}{l}\text { Re- } \\
\text { vers } \\
\text { e }\end{array}$ & $\begin{array}{l}\text { Gravel layer } \\
\text { including } \\
\text { sand }\end{array}$ & 1.5 & 2 & 5.5 & $\begin{array}{l}60^{\circ}- \\
70^{\circ}\end{array}$ \\
\hline 24 & $\begin{array}{l}\text { Nor } \\
\text { mal }\end{array}$ & $\begin{array}{l}\text { Gravel, sand } \\
\text { and gravel } \\
\text { sand }\end{array}$ & $\begin{array}{c}18 . \\
4\end{array}$ & 15 & $\underset{*}{21.2}$ & $\begin{array}{l}80^{\circ}- \\
85^{\circ}\end{array}$ \\
\hline 25 & $\begin{array}{l}\text { Nor } \\
\text { mal }\end{array}$ & Gravel & $\begin{array}{c}10 . \\
8\end{array}$ & 9 & 10.8 & $\begin{array}{l}55^{\circ}- \\
70^{\circ}\end{array}$ \\
\hline 26 & $\begin{array}{l}\text { Re- } \\
\text { vers } \\
\text { e }\end{array}$ & $\begin{array}{l}\text { Sand and } \\
\text { gravel, clay }\end{array}$ & 5.0 & 9 & 6.0 & $\begin{array}{l}80^{\circ}- \\
85^{\circ}\end{array}$ \\
\hline 27 & $\begin{array}{l}\text { Re- } \\
\text { vers } \\
\text { e }\end{array}$ & $\begin{array}{l}\text { Sand and } \\
\text { gravel, } \\
\text { brown red } \\
\text { sandy mud- } \\
\text { stone }\end{array}$ & 2.4 & 4 & 4.3 & $75^{\circ}$ \\
\hline 28 & $\begin{array}{l}\text { Nor } \\
\text { mal }\end{array}$ & $\begin{array}{l}\text { Footwall of } \\
\text { Lava, hang- } \\
\text { ing wall of } \\
\text { sand and } \\
\text { gravel }\end{array}$ & 1.0 & 4 & 3.4 & $\begin{array}{l}70^{\circ}- \\
80^{\circ}\end{array}$ \\
\hline 29 & $\begin{array}{l}\text { Re- } \\
\text { vers }\end{array}$ & $\begin{array}{l}\text { Gravel, vol- } \\
\text { canic rock }\end{array}$ & 2.8 & 4 & 3.9 & $\begin{array}{l}60^{\circ}- \\
85^{\circ}\end{array}$ \\
\hline
\end{tabular}




\begin{tabular}{|c|c|c|c|c|c|c|}
\hline & $\mathrm{e}$ & & & & & \\
\hline 30 & $\begin{array}{l}\text { Nor } \\
\text { mal }\end{array}$ & $\begin{array}{l}\text { Fine sand } \\
\text { and gravel }\end{array}$ & 6.6 & 9 & 7.8 & $\begin{array}{l}70^{\circ}- \\
80^{\circ}\end{array}$ \\
\hline 31 & $\begin{array}{l}\text { Re- } \\
\text { vers } \\
\text { e }\end{array}$ & $\begin{array}{l}\text { Sand gravel } \\
\text { breccia }\end{array}$ & 6.4 & 7 & 10.0 & $\begin{array}{l}50^{\circ}- \\
65^{\circ}\end{array}$ \\
\hline 32 & $\begin{array}{l}\text { Re- } \\
\text { vers } \\
\text { e }\end{array}$ & $\begin{array}{l}\text { Gravel, } \\
\text { sandy clay }\end{array}$ & 9.0 & 7 & $\underset{*}{13.0}$ & $\begin{array}{l}65^{\circ}- \\
70^{\circ}\end{array}$ \\
\hline 33 & $\begin{array}{l}\text { Nor } \\
\text { mal }\end{array}$ & $\begin{array}{l}\text { Gravel, } \\
\text { sandy clay }\end{array}$ & $\begin{array}{c}12 . \\
5\end{array}$ & 7 & $15^{*}$ & $\begin{array}{l}70^{\circ}- \\
75^{\circ}\end{array}$ \\
\hline 34 & $\begin{array}{l}\text { Nor } \\
\text { mal }\end{array}$ & $\begin{array}{l}\text { Yellow soil } \\
\text { gravel }\end{array}$ & 6.5 & 7 & 10.5 & $\begin{array}{l}65^{\circ}- \\
70^{\circ}\end{array}$ \\
\hline 35 & $\begin{array}{l}\text { Re- } \\
\text { vers } \\
\mathrm{e}\end{array}$ & $\begin{array}{l}\text { Gravel and } \\
\text { gravel pack- } \\
\text { ing sand }\end{array}$ & 8.4 & 7 & $\underset{*}{21.0}$ & $\begin{array}{l}45^{\circ}- \\
50^{\circ}\end{array}$ \\
\hline 36 & $\begin{array}{c}\text { Re- } \\
\text { vers } \\
\mathrm{e} \\
\end{array}$ & $\begin{array}{l}\text { Gravel and } \\
\text { gravel pack- } \\
\text { ing sand }\end{array}$ & 4.0 & 5 & 14.3 & $\begin{array}{l}35^{\circ}- \\
45^{\circ}\end{array}$ \\
\hline
\end{tabular}

Note: Wo is the previous earthquake caused the surface rupture trace of the maximum width; $\mathrm{W}_{\mathrm{Y}}$ is probe slot on the geology strong deformation band width, D is the biggest fault vertical dislocation, theta is dip angle of the fault plane. The gentle slope is tilted less than 10 degrees, the number refers to the number of probe faults or surface groove profile of rupture trace number. ${ }^{*}$ on behalf of some of the probe slot to the data completely given the actual $\mathrm{W}_{\mathrm{Y}}$.

Two methods of statistical analysis of the width of the fractured zone and the statistical method of the profile of the width of the ground surface are used.

(1) the width of the fracture zone is given to give the upper bound and the average value of the permanent geological deformation width;

(2) profile trench statistical method to determine the surface rupture width is more economical and reliable, such as to establish of the scarps vertical height $(\mathrm{H})$ and maximum deformation with the formula of width $\left(\mathrm{W}_{\mathrm{D}}\right)$, or strong deformation zone width mean value and several times the standard deviation and the formula.

\section{ACKNOWLEDGMENTS}

Thank you for the support of Teachers' Scientific Research Fund of China Earthquake Administration (20130106) andSpecial Fund of Fundamental Scientific Research Business Expense for Higher School of Central Government (Projects for creation teams) (ZY20160101)

\section{REFERENCES}

1) Glenn Borchardt. 2010. Establishing appropriate setback widths for active faults, Environmental \& Engineering Geoscience, 16(1): 47-53.

2) Huang Fugang, Wang Jinnan. 1993. Faults in Northwest Yunnan broken belt width and fault distance of the statistical relationship between syndrome. Earthquake research, 16 (4):384-390.

3) James Mccalpin. 1987. Recommended setback distances from active normal faults. Proceedings of the Symposium on Engineering Geology and Soils Engineering, 23, 35-56.

4) Sun Pingshan, Li Xiaojun, Peng Xiaobo. 2009. Statistical analysis and probabilistic analysis method for surface rupture of strong earthquakes. Harbin: China Earthquake Administration, the old expert Foundation funded project report. 
5) Wu Chuanyong, Shen Jun, Shi Jie, et al. 2011. The surface deformation characteristics and the strong deformation band width. Seismic geology, 33 (1): 56-67.

6) Xu Xiwei, Zhao Boming, Ma Shengli, et al. 2011. Prediction method and application of active fault earthquake disaster. Beijing: Science Press.

7)Zhang Jianyi, Bo Jingshan, Li Ping, et al. 2010. The influence of surface rupture to the buildings caused by M s7.1 Yushu earthquake. Earthquake Engineering and Engineering Vibration, 30(6): 24-31.

8)Zhang Jianyi, Bo Jingshan Yuan Yi fan, et al. 2012. A review on Active Fault and its Setback Research. Journal of natural disasters, 2 (2): 9-18.

9)Zhang Jianyi.2015. Active fault setback research on engineering sites. Institute of Engineering Mechanics, China Earthquake Administration, Harbin. 